\title{
ACADEMIC READING PADA PROGRAM MAGISTER FITK UIN SYARIF HIDAYATULLAH JAKARTA
}

\author{
Fahriany
}

fahriany@ymail.com

Fakultas Ilmu Tarbiyah dan Keguruan UIN Syarif Hidayatullah

Jakarta

\begin{abstract}
The objective of the study is to get comprehensive understanding of English reading instructional process which can increase English reading competence of students at Master program, Faculty of Tarbiya and teacher training UIN Syarif Hidayatullah Jakarta. The component of instruction consists of instructional objective, form and function of text, instructional procedure, form and function of instructional activity, the role of student and teacher, and evaluation in reading instruction. This research is a qualitative study done in May of 2013-2014 academic year. The data is collected by using the techniques of observation, interview and document analysis. The data is analyzed by taxonomy analysis and theme analysis. The result shows that the English reading instruction runs well. It can develop student's reading competence based on their academic need to understand academic English texts. It is done by using many kinds of texts with three reading procedures namely pre reading, whilst reading and post reading. These procedures facilitate the students to be able to use interactive process.
\end{abstract}

Keywords: academic reading, reading procedures

\section{INTRODUCTION}

Di Indonesia, Bahasa Inggris mempunyai peran penting dalam memajukan Ilmu Pengetahuan dan Teknologi. Posisi bahasa Inggris dalam perkembangan Ilmu Pengetahuan dan Teknologi di negara berkembang seperti Indonesia sangat strategis. Bahasa Inggris penting sebagai alat komunikasi internasional dan sebagai alat untuk memperoleh Ilmu Pengetahuan dan Teknologi (Beer, 2007, h. 36-37).

Di Indonesia, Bahasa Inggris dipelajari sebagai mata pelajaran wajib sejak siswa berada di Sekolah Menengah Pertama (SMP), Sekolah Menengah Atas (SMA) sampai tingkat awal di perguruan tinggi. Tujuan utama pembelajaran Bahasa Inggris pada tingkat universitas adalah untuk mengembangkan keterampilan membaca dan memahami teksteks yang berhubungan dengan wacana akademik.
Membaca menduduki posisi yang sangat penting bagi kehidupan manusia. Aktivitas membaca adalah kebutuhan bagi setiap individu sehingga untuk hidup dalam masyarakat dan teknologi modern seseorang harus melek huruf. Membaca dalam bahasa Inggris diharapkan dapat meningkatkan minat dan motivasi mahasiswa untuk dapat menguasai Ilmu Pengetahuan dan Teknologi.

Keterampilan membaca merupakan salah satu keterampilan bahasa yang harus diberikan kepada siswa dalam belajar bahasa Inggris. Hal ini sesuai dengan fakta bahwa para siswa tidak bisa membaca buku atau literatur dalam bahasa Inggris. Oleh karena itu, keterampilan membaca harus ditekankan dalam pengajaran bahasa Inggris.

Menurut Bolinger (2002, h. 10) sukses atau gagalnya pengajaran suatu bahasa asing, terutama keterampilan membaca bahasa Inggris dipengaruhi oleh faktor-faktor non linguistik (contoh: siswa, guru, metode, 
materi, fasilitas, waktu yang tersedia dan lain-lain). Sayangnya faktor-faktor ini tidak mendapat perhatian. Coady dan Barkman (2009, h.15) menyatakan bahwa sebagian besar kegagalan di sekolah dapat disebabkan sistem instruksional yang tidak tepat, sehingga siswa mengalami kegagalan. Dalam prakteknya, yang mendapat penekanan adalah pengembangan keterampilan membaca, bukan pengembangan kemampuan berbahasa sebagaimana seharusnya. Hal pertama yang perlu dianalisa adalah masalah pengajaran kosa kata yang kurang memperhatikan kebutuhan mahasiswa pada umumnya. Pengajaran bahasa Inggris selama ini hanya menekankan masalah bentuk bukan fungsi kata-kata tersebut. Kedua, penguasaan komponen berbahasa tidak menjadi target. Ketiga keterampilan berbahasa disajikan dalam kesempatan yang bersamaan. Keempat, pengajar harus menyajikan topiktopik yang sangat banyak. Kelima, pengajar tidak dilatih untuk menempatkan siswanya sesuai dengan kemampuan membacanya. Keenam, pengajar tidak mempersiapkan proses pembelajaran membaca dengan rinci. Hal lain yang sangat berperan adalah desain dari materi pelajaran bahasa Inggris itu sendiri. Merancang suatu materi pelajaran bahasa Inggris yang dapat mempermudah pemahaman bahasa Inggris untuk tujuan akademis perlu dilakukan melalui penulisan materi pelajaran sesuai dengan kebutuhan siswa.

Kegagalan pembelajaran membaca dapat dihindari jika pengajar menopang kebutuhan mahasiswa untuk membaca dan belajar sebagai kekuatan internal. Pada akhirnya mahasiswa menjadi pembaca yang dapat mengatur diri, fasih, dan bertanggung jawab. Untuk mencapai keberhasilan dalam pembelajaran membaca bahasa Inggris ada beberapa faktor yang harus diperhatikan yaitu silabus, pengajar, dan siswa. Karena itulah penelitian ini memfokuskan pada proses belajar mengajar membaca bahasa Inggris di pada Program Magister FITK UIN Syarif Hidayatullah Jakarta yang meliputi komponen tujuan, bentuk dan jenis teks, prosedur kegiatan, bentuk kegiatan, peran mahasiswa dan dosen serta evaluasi pembelajaran.

\section{ACUAN TEORETIS \\ Hakikat Membaca}

Dalam arti umum, membaca adalah apa yang terjadi ketika orang melihat teks dan memberi makna terhadap simbol tertulis pada teks (De Lopez et al., 2007, h.15). Teks dan pembaca adalah dua entitas fisik penting bagi proses terjadinya membaca. Walaupun demikian, interaksi antara pembaca dengan teks merupakan kegiatan membaca yang sebenarnya. Dalam interaksi itu terjadi proses pemaknaan yang dilakukan pembaca terhadap teks.

Membaca adalah sebuah proses interaktif dimana pembaca menggunakan kode, analisis konteks, pengetahuan awal, bahasa, dan strategi kontrol eksekutif untuk memahami teks (Harris \& Hodges, 2000, h.203). Dengan ungkapan yang berbeda tetapi memiliki nuansa makna yang senada dengan batasan tersebut, Kaplan dan Shaw (2003, h.12) menyatakan bahwa membaca adalah proses mengenali, menafsirkan dan mempersepsi bahan tertulis atau tercetak. Pemahaman bacaan adalah kesanggupan memahami makna bahan tertulis yang mencakup kesadaran strategi untuk mengerti.

Membaca adalah sebuah proses psikolinguistik dimulai dengan representasi awal linguistik yang diwujudkan penulis hingga pemaknaan yang dibangun pembaca. Di dalamnya terjadi interaksi antara bahasa dan pikiran. Penulis mengungkapkan pikiran ke dalam bahasa dan pembaca mencerna bahasa dalam pikiran (Kendall \& Hunter, 2000, h.12).

Menurut Langer (2002, h.179), membaca tergantung pada keberhasilan interaksi beberapa faktor (1) kecakapan konseptual yang mengacu pada kapasitas intelektual seperti analisis, sintesis, dan inferensi; (2) latar belakang pengetahuan yang mencakup pengetahuan sosiokultural; dan (3) strategi proses yang mengacu pada kecakapan dan keterampilan membangun kembali makna teks melalui penyampelan berdasarkan pengetahuan korespondensi graphem-morfofonem, informasi silabimorfem, informasi sintaktik, makna leksikal, makna kontekstual, dan strategi kognitif.

Menurut Mackey (2006, h.1) membaca adalah proses yang digunakan untuk memperoleh pesan yang disampaikan penulis 
tanpa batas dan ruang. Dalam pengertian ini membaca merupakan upaya menangkap informasi pada teks. Selanjutnya, Widdowson (2003, h.350) menyatakan bahwa membaca adalah suatu proses berpikir, pembaca menjadi partisipan aktif. Pembaca tidak saja memperhatikan simbol-simbol tertulis secara harfiah tetapi juga menghubungkan antara konsep- konsep yang dimilikinya, baik pengetahuannya maupun pengalaman pragmatisnya terhadap simbol-simbol tersebut. Sejalan dengan pendapat ini, Mason dan Kathryn (2006, h.49) mengemukakan bahwa membaca bukan sekedar menyuarakan lambang- lambang bunyi atau mentransfer teks-teks tertulis ke dalam bahasa lisan melainkan juga melibatkan pengingatan kembali, penalaran, penerapan dan pemecahan masalah. Membaca merupakan aktivitas komunikatif dimana ada hubungan timbal balik antara si pembaca dan isi teks. Dengan demikian taraf pendidikan, intelegensi, sikap, motivasi dan kemampuan berbahasa akan menentukan proses penyerapan bahan bacaan. Berdasarkan pendapat ini maka jika ada dua orang pembaca membaca suatu teks yang sama dapat saja memperoleh makna yang berbeda tergantung dari latar belakang pengetahuan dan pengalaman masing-masing pembaca. Hal ini sejalan dengan pendapat yang dikemukakan oleh Miller (2000, h.54) bahwa teks bacaan memiliki potensi makna yang berbeda dari satu pembaca dengan pembaca lain. Makna dipengaruhi banyak faktor tetapi yang paling menentukan adalah pengetahuan pembaca. Dengan demikian makna suatu teks dimunculkan oleh pembaca dalam interaksinya dengan teks. Sebagaimana pernyataan Murdick dan Ross (2001, h.164) bahwa membaca adalah mengkonstruksi makna melalui proses interaksi antara pembaca, teks, konteks dan strategi pemahaman. Jadi pemahaman yang diperoleh oleh pembaca merupakan hasil proses interaksi antara pembaca, strategi yang digunakan, materi yang dibaca, dan konteks bacaan.

\section{Kegiatan Pra-membaca}

Setiap manusia memiliki struktur
kognitif (cognitive structure) yakni pengumpulan pengalaman dan konsepkonsep yang tersimpan dalam otak. Dalam struktur kognitif terbentuk pola-pola atau sistem kategorisasi sesuai kultur dan pengalaman seseorang. Itulah sebabnya kultur orang Indonesia memiliki struktur kognitif berbeda dengan orang dari kultur yang berbeda, misalnya dengan orang Inggris. Sebagai contoh, orang Indonesia memiliki pengalaman dan kultur spesifikasi kategori jenis makanan yang disebut beras (gabah, padi, dan nasi) sedangkan orang Inggris hanya mengenal rice untuk semua spesifikasi tersebut. Demikian juga misalnya kultur masyarakat Eskimo yang memiliki sistem kategorisasi tentang snow lebih banyak daripada masyarakat bangsa Arab.

Pengaktifan pengetahuan sebelum membaca merupakan komponen penting dalam pembelajaran membaca yang efektif. Latar belakang pengetahuan yang dibawa pembelajar ke dalam teks akan mempengaruhi pengalaman bacaan. Akan sulit dibayangkan apabila pembaca tidak memiliki latar belakang pengetahuan terhadap teks. Pemahaman berlangsung ketika informasi yang sedang dibaca berhubungan dengan informasi yang telah dimiliki pembaca.

\section{Kegiatan Waktu Membaca}

Kegiatan tahap membaca (whilst reading) bertujuan mengembangkan kompetensi membaca baik memahami atau membangun informasi dalam teks (Nuttal, 2007). Fase ini merupakan fase lanjutan dari sebelumnya yang pada dasarnya memiliki hubungan erat. Kegiatan yang dilaksanakan dalam mengantisipasi makna memberi andil pada pembangunan makna selama membaca.

Pada fase ini pembaca berinteraksi langsung dengan teks dalam proses membangun makna. Berdasarkan pernyataan Rossi dan Gasser (2003, h.10), membangun adalah fase interaktif, pembelajar terlibat secara aktif dalam memproses apa yang dipelajari dan memadukannya dengan skema mereka. Agar belajar benar-benar terjadi, pembelajar harus menjadi partisipan aktif ketika memikirkan informasi dan ide-ide baru serta memperhatikan hubungan dengan konsep dan gagasan yang dipelajari sebelumnya.

Rubin dan Thomson (2005a) menyatakan bahwa pembaca harus tahu apa yang dilakukan untuk memahami informasi 
selama membaca, secara independen atau dengan yang lain. Dalam membangun makna, ada informasi yang perlu mendapatkan prioritas secara seksama, ada juga yang kurang. Tidak semua informasi menjadi pusat perhatian. Agar dapat membangun makna, baik berupa gagasan utama maupun gagasan tambahan, pembaca perlu mencamkan tujuan membaca dengan baik. Tujuan membaca dalam pembelajaran identik dengan arah melaksanakan tugas-tugas setelah membaca.

Dengan mengaitkan tujuan membaca sebagai fokus, pembelajar perlu mencermati kata-kata atau konsep penting, jalinan informasi, dan pola strukturnya. Cara yang dapat dilakukan ialah memberi garis bawah, mewarnai, menandai, mencatat, dan sebagainya. Selama membaca itu, mereka memonitor pemahaman, memaknai, menginterpretasi, membaca ulang, bertanya pada diri sendiri atau juga kepada pengajar atau teman. Tahap waktu membaca adalah kegiatan yang mempersoalkan (1) bagaimana pembelajar memahami teks yang sedang di baca; (2) bagaimana pembelajar mendapatkan informasi baik bersifat umum maupun khusus; (3) bagaimana pembelajar mendapatkan informasi tersurat dan tersirat; (4) bagaimana pembelajar mendapatkan informasi dengan cepat dan lain sebagainya.

\section{Kegiatan Pasca-Membaca}

Pasca-membaca (post reading)
merupakan kegiatan tahap akhir pembelajaran membaca yang dapat diisi dengan menghubungkan apa yang telah dibaca dengan pengalaman riil pembelajar. Dapat juga dimasukan bagaimana pendapat pembelajar tentang isi bacaan apakah mereka setuju, tidak setuju, senang atau tidak senang dan apa alasannya. Yang pokok adalah bagaimana menghubungkan antara isi bacaan dengan kehidupan sehari-hari pembelajar. Rubin dan Thomson (2005b) menyatakan bahwa kegiatan ini ditujukan untuk menambah kualitas pemahaman dan minat pembelajar pada pelajaran membaca.

Kegiatan pembelajaran pasca-membaca menurut Smith (2000) bertujuan untuk mengembangkan kualitas pemahaman bacaan. Untuk mengembangkan kualitas pemahaman tersebut kegiatan dapat diarahkan kembali ke teks dan di luar teks atau kombinasi keduanya.

\section{Teks Pembelajaran Membaca Bahasa Inggris}

Setiap jenis teks tersusun dari fiturfitur bahasa yang berbeda satu sama lain sehingga konteks maknanya berbeda antar teks. Demikian juga dalam dua jenis teks yang sama tetapi masing-masing memuat hubungan interpersonal yang berbeda berpeluang mengandung makna yang berbeda. Termasuk juga teks yang dihasilkan oleh dua penulis yang berlatar belakang pengetahuan atau budaya yang berbeda berpeluang besar menghasilkan makna yang berbeda pula.

Menurut Smith (2000), secara garis besar makna teks dipengaruhi unsur bahasa dan nonbahasa. Unsur bahasa secara lahiriyah terlihat dalam sebuah teks., misalnya kalimat, kata, paragraf, dan tandatanda baca. Sebuah teks yang berbentuk buku seberapapun banyak halamannya pasti tersusun dari paragraf-paragraf. Sebuah paragraph tersusun dari sejumlah kalimat yang memiliki satu ide pokok. Ide pokok dijelaskan oleh ide penjelas. Setiap ide penjelas dituangkan dalam satu kalimat. Kesemuanya membentuk kesatuan. Pembentukan sebuah paragraf misalnya harus memenuhi syarat kohenrensi atau kepaduan, yakni hubungan timbal balik yang baik antara unsur-unsur pembentuk kalimat maupun antara kalimat dan kalimat. Untuk memperoleh kepaduan dibutuhkan alat-alat bahasa, seperti pengulangan kata, penggantian kata, seperti kata ganti diri maupun dengan kata lain yang bersinonim, penambahan kata "itu," "tersebut," dan menggunakan kata transisi. Semua itu disebut alat-alat kohesif.

Penggunaan alat kohesif dengan kata ganti diri, misalnya, meminta pembaca menginterpretasikan siapa yang dirujuk, pembaca harus melihat kembali kata ganti diri tersebut mengacu kepada benda, hal, atau siapa yang telah ditulis pada bagian sebelumnya (Smith, 2000, h.46-47). Unsur bahasa terdiri dari konteks budaya dan konteks situasi.

\section{Evaluasi Pembelajaran Membaca Bahasa Inggris}

Melihat perkembangannya, evaluasi terdiri dari evaluasi proses dan evaluasi hasil. Menurut Straiger (2003), dalam kegiatan 
membaca belum ada suatu alat yang sesuai untuk digunakan sebagai alat evaluasi proses membaca pemahaman seseorang. Yang ada adalah alat untuk mengetahui sejauh mana pemahaman seseorang terhadap suatu teks. Evaluasi hasil belajar bertujuan mengetahui tingkat keberhasilan yang dicapai setelah mengikuti kegiatan pembelajaran dengan berbasis kompetensi (Straiger, 2003, h.20).

\section{Penelitian Yang Relevan}

Straiger (2003) menyimpulkan hasil penelitiannya bahwa ketika pembaca dipajankan dengan teks yang bermuatan budaya asing maka persepsi hubungan teks akan menurun dibandingkan dengan budaya yang diketahui. Penurunan hubungan pada tingkatan linguistik menunjukan penurunan pemahaman yang berkaitan dengan pengalaman pada tingkatan isi. Sebagai implikasi dari temuan Straiger ini dalam pengajaran bahasa ialah kesalahan linguistik tidak selamanya disebabkan oleh kurangnya pengetahuan linguistik tetapi dapat disebabkan oleh kurangnya pengetahuan latar belakang si pembaca itu sendiri terhadap teks. Dengan demikian dalam pengajaran membaca, latihan yang diarahkan pada pemahaman tentang isi bacaan lebih efektif dibandingkan dengan sekedar pemajanan aspek-aspek kebahasaan.

Selanjutnya adalah penelitian yang dilakukan oleh Stren (2008) untuk mengetahui keefektifan pre-reading pada pembelajaran membaca. Penelitian dilakukan terhadap 99 responden pembelajar bahasa kedua dengan tingkat kemampuan membaca yang berbeda-beda. Instrumen materi tes yang terdiri dari sembilan judul tes bacaan yang diberikan dalam tiga cara. Pertama dengan pre-reading, kedua dengan kosa kata, dan ketiga dengan membaca tes. Bagian prereading diberikan untuk mendekatkan skemata pembaca terhadap isi teks, dan kosa kata diberikan untuk mengenalkan kata-kata esensial kepada pembaca, sedangkan membaca tes untuk menyesuaikan interpretasi pembaca terhadap tes bacaan. Hasil penelitian menunjukan bahwa penerapan pre-reading lebih efektif diberikan pada pembaca dengan kemampuan membaca tingkat dasar, sedangkan pada perlakuan kosa kata dan membaca tes lebih efektif diberikan pada pembaca yang memiliki kemampuan membaca tingkat menengah dan mahir.

\section{METODE PENELITIAN}

Metode yang digunakan dalam penelitian ini adalah metode kualitatif. Peneliti berusaha mendeskripsikan yang dilakukan, diketahui, dibuat dan digunakan orang. Deskripsi muncul setelah terlebih dahulu memahami aspek- aspek tersebut berdasarkan sudut pandang orang- orang yang diamati, bukan dari sudut pandang peneliti (Spradley, 1980, h.86). Peneliti mengungkap makna apa yang dilakukan mahasiswa dan dosen, apa yang mereka ketahui, dan apa- apa yang mereka buat dan gunakan dalam proses pembelajaran. Pendekatan kualitatif digunakan untuk mengkaji dokumen, ucapan, dan perilaku mahasiswa dan dosen dalam latar alamiah. Yang dimaksud dengan dokumen ialah pedoman dan materi yang dibuat dan digunakan dosen dan mahasiswa. Yang dimaksud ucapan dan perbuatan ialah apa yang dilakukan oleh dosen dan mahasiswa dalam kegiatan pembelajaran membaca bahasa Inggris. Sedangkan latar alamiah adalah kelas tempat terjadinya kegiatan pembelajaran sebagaimana adanya tanpa perubahan atau rekayasa dari peneliti.

Tempat penelitian dilakukan di program magister FITK UIN Syarif HidayatulIah Jakarta. Penelitian dilakukan pada akhir bulan Mei sampai dengan akhir bulan Juli 2014 termasuk penyusunan instrumen penelitian. Pengumpulan data dilaksanakan dengan teknik pengamatan, wawancara, dan analisis dokumen. Urutan ini bukan merupakan prosedur tetap karena pelaksanaan di lapangan disesuaikan dengan kebutuhan. Hal ini dilakukan untuk mengikuti latar penelitian yang sebenarnya tanpa ada rekayasa yaitu sesuai jadwal kuliah serta sumber- sumber data. Selama pengumpulan data, peneliti menggunakan pedoman pengamatan, wawancara, dan analisis dokumen.

Penelitian ini menggunakan prosedur penelitian kualitatif yakni (1) memilih situasi sosial, (2) mengadakan pengamatan terlibat, (3) membuat catatan lapangan., (4) melaksanakan pengamatan deskriptif, (5) membuat analisis domain, (6) melakukan pengamatan terfokus, (7) membuat analisis 
taksonomi, (8) melakukan pengamatan selektif, (9) melakukan analisis komponen, (10) membuat analisis tema, (11) membuat catatan teori, dan (12) membuat teori kualitatif. Peneliti mulai melaksanakan analisis sejak langkah ke 4 (pengamatan deskriptif) sampai pada langkah ke 10 (analisis tema). Langkah selanjutnya ialah merumuskan makna atas dasar analisis domain, analisis taksonomi, analisis komponen, dan analisis tema. Adapun pemeriksaan atau pengecekan keabsahan data dilakukan melalui konfrontatif, kredibilitas, dipendebilitas dan konfirmabilitas.

\section{TEMUAN PENELITIAN}

\section{Tujuan Pembelajaran Membaca Bahasa Inggris}

Berdasarkan hasil wawancara, program magister FITK UIN Syarif Hidayatullah Jakarta sudah menggunakan Kurikulum Berbasis Kompetensi (KBK). Pada keterampilan membaca tujuannya yaitu membentuk kompetensi menggunakan ragam bahasa tulis dengan lancar dan akurat dalam wacana interaksional dan/atau monolog terutama berkenaan dengan wacana yang berbentuk naratif, prosedur, spoof/recount, report, dan news item.

\section{Bentuk dan Fungsi Teks Pembelajaran Membaca}

Materi pembelajaran membaca adalah teks bahasa Inggris yang dikemas dalam bentuk penyelesaian tugas yang dilakukan dengan cara membaca nyaring dan membaca diam. Fungsi menyelesaikan tugas yaitu agar mahasiswa memiliki pengalaman belajar bagaimana membaca dengan baik. Dengan kata lain mahasiswa dapat memperoleh kompetensi membaca yang dibutuhkan yakni dapat memahami/ mendapatkan informasi atau membangun makna teks-teks bahasa Inggris yang dibutuhkan dalam lingkungan akademik mereka dengan cara membaca nyaring atau diam. Membaca nyaring bertujuan mengembangkan kompetensi membaca pada aspek pengucapan dan pemahaman bacaan. Sedangkan membaca diam khusus terpusat pada pengembangan pemahaman bacaan.

\section{Prosedur dan Fungsi Tahapan dan Kegiatan Pembelajaran Membaca}

Secara umum prosedur pembelajaran membaca Bahasa Inggris sama dengan pembelajaran mata kuliah lain yakni terdiri dari tiga tahapan kegiatan. Ketiga tahapan pembelajaran tersebut adalah tahap awal pembelajaran, tahap inti pembelajaran dan tahap akhir pembelajaran.

Tahap pra-membaca dilakukan sebelum mahasiswa membaca teks. Kegiatan ini diisi dengan tanya jawab antara dosen dan mahasiswa secara lisan dan tertulis, baik ditujukan secara umum kepada semua mahasiswa, maupun secara individu.

Tahap kegiatan membaca dilakukan mahasiswa untuk belajar bagaimana membaca yang baik, yakni memahami teks yang dilakukan dengan membaca nyaring dan membaca diam. Kegiatan membaca nyaring seperti yang dipimpin oleh dosen AJ dilakukan dengan terlebih dahulu mempersilahkan mahasiswa yang berinisiatif mau membaca dan dilanjutkan dengan menunjuk mahasiswa lainnya secara bergilir.

Tahap pasca-membaca dilakukan di kelas dengan menulis dan berbicara. Pokok kegiatan pada tahap ini sebagai aplikasi atau penggunaan pengetahuan/informasi yang diperoleh dari teks yang telah dibaca ke dalam lingkup kehidupan mahasiswa.

\section{Bentuk dan Fungsi Kegiatan Pembelajaran}

Berdasarkan pengamatan pada kegiatan di kelas dan wawancara tentang kegiatan pembelajaran membaca bahasa Inggris berbasis kompetensi menunjukan bahwa dosen telah mengembangkan kegiatan membaca menjadi dua yakni membaca nyaring dan membaca diam. Ini berarti untuk mencapai tujuan pembelajaran membaca memahami/mendapatkan informasi dalam teks atau memahami/membangun makna teks dilakukan dengan dua cara yakni membaca nyaring dan membaca diam.

\section{Peran Mahasiswa}

Pada tahap pra-membaca, peran mahasiswa adalah merespon atau menjawab secara lisan atau tulisan pertanyaanpertanyaan pra-membaca yang diajukan dosen. Pertanyaan tersebut dijawab oleh mahasiswa agar mendekatkan atau 
mengakrabkan mereka dengan teks yang akan dibaca. Mahasiswa menjawab dengan lisan, misalnya, dari pertanyaan dosen, " $D o$ you know what hero is?" sebelum kegiatan membaca teks yang berjudul, "Local Heroes" mereka secara bergiliran memberikan jawaban misalnya: "My father and mother are heroes".

Pada waktu membaca, peran mahasiswa sebagai pelaku pengembangan pemahaman untuk dirinya sendiri yang dilakukan dengan membaca teks baik membaca nyaring maupun diam. Pada kegiatan membaca nyaring, kegiatan membaca dilakukan secara bergilir, yakni satu orang membaca dan yang lainnya mendengarkan secara seksama bagaimana bunyi bacaan dan kemudian memberi komentar selesai bacaan. Pada waktu membaca pemahaman, mahasiswa menyelesaikan tugas menjawab soal-soal berdasarkan teks. Soal tersebut dijawab berdasarkan informasi yang diperoleh dari teks dan bukan jawaban yang diperoleh di luar teks dengan tanpa membaca teks. Peran mahasiswa pada tahap ini juga menentukan keberhasilan belajar mereka. Mahasiswa menyelesaikan tugas supaya mengalami bagaimana memahami teks atau bagaimana mendapatkan informasi yang terkandung dalam teks melalui menjawab soal-soal yang diberikan dosen secara lisan atau tertulis.

Peran mahasiswa dalam kegiatan membaca adalah sebagai pelaku. Adapun usaha mencapai mencapai tujuan yang diharapkan dalam kegiatan pembelajaran tampak dari selesainya mengerjakan tugas. Tetapi kekurangannya mahasiswa tidak mengetahui tujuan dari peran-peran yang dilakoninya sehingga mereka tidak mengerjakannya dangan serius.

Pada tahap pasca membaca mahasiswa mengaitkan informasi teks dengan pengalaman mereka di luar teks. Misalnya pada kelas yang dipimpin oleh dosen SY pada pembelajaran dengan teks. "Anti Globalization: Problems and Solution." Dosen menugaskan mahasiswa mencari masalah yang disebabkan oleh globalisasi yang mereka temui dalam kehidupan sehari-hari dan bagaimana solusinya menurut mereka. Mahasiswa bekerja secara berkelompok untuk menemukan beberapa masalah yang mereka identifikasi dalam kehidupan masyarakat dan bagaimana solusinya menurut pengalaman dan pengetahuan mereka.

\section{Peran Dosen}

Pada tahap pra membaca, pertamatama dosen menyiapkan mahasiswa sebelum membaca teks dengan menanyakan hal-hal yang berkaitan dengan teks yang akan dibaca mahasiswa. Pertanyaan atau tugas yang diberikan kepada mahasiswa dalam bentuk lisan dan tulisan. Disamping itu pertanyaan dosen kadang diberikan dengan alat bantu gambar, misalnya pada pembelajaran yang dipimpin oleh dosen AJ menunjukkan gambar sembari menanyakan, "What do you think about the picture?" Pertanyaan-pertanyaan yang disampaikan kepada mahasiswa pada tahap pra-membaca merupakan usaha dosen mengaitkan pengalaman mahasiswa sebelumnya dengan informasi yang akan dibaca dalam teks.

Pada waktu membaca, dosen terlebih dahulu menyampaikan informasi tentang apa yang akan dilakukan dalam membaca. Apakah membaca nyaring atau membaca diam, dan juga apakah dilakukan secara individu atau kelompok. Peran dosen pada kegiatan ini adalah menjelaskan cara membaca kepada mahasiswa. Selama membaca teks, misalnya membaca nyaring, dosen memperhatikan dan mendengarkan bunyi bacaan mahasiswa dan memberi nilai mahasiswa yang bersangkutan. Kegiatan ini dapat memberi motivasi kepada mahasiswa untuk membaca sebaik mungkin. Termasuk mahasiswa yang belum sampai gilirannya untuk mempersiapkan diri baik-baik. Disamping penilaian dosen, seorang mahasiswa ditunjuk untuk memberikan penilaian sejawat. Kegiatan ini juga efektif untuk memotivasi mahasiswa supaya tetap bekerja serius.

Pada tahap pasca-membaca, dosen memberikan tugas tahapan kepada mahasiswa yang masih ada hubungannya dengan teks. Dalam kegiatan ini mahasiswa mencoba mengaitkan informasi apa yang diperoleh dalam teks ke dalam kehidupan mahasiswa sehari-hari atau ke dalam pengalaman dan pengetahuan mahasiswa sebelumnya. Sebelumnya dosen terlebih dahulu menyampaikan intruksi dan menjelaskan cara kerja tugas. Pada waktu 
mahasiswa melakukan tugas, dosen mengamati mahasiswa dan kadang memberi motivasi dengan bertanya misalnya "finish?" atau memberi motivasi dengan mendekati mahasiswa dan membaca apa yang sedang ditulis.

\section{Bentuk dan Fungsi Evaluasi Pembelajaran Membaca}

Evaluasi yang dilakukan pada tahap pra-membaca diberikan oleh dosen kepada mahasiswa dalam bentuk pertanyaanpertanyaan lisan/tulisan. Misalnya, 'Do you know what hero is?" atau "What is the picture about?" pertanyaan-pertanyaan dalam tahap ini bukan untuk mengukur kemampuan mahasiswa menjawab pertanyaan tetapi sekedar menarik perhatian mahasiswa pada pembelajaran yang akan dipelajari dan sekaligus mengarahkan perhatian mahasiswa pada suatu topik pelajaran. Jadi setelah proses tanya jawab antara dosen dan mahasiswa, mahasiswa akan memperoleh kesiapan awal dalam membaca suatu teks tertentu misalnya mahasiswa memiliki kesiapan mental, mahasiswa memiliki minat untuk membaca teks, dan memiliki harapanharapan atau bayangan awal tentang apa yang akan dibaca dalam teks.

\section{SIMPULAN}

Berdasarkan enam fokus penelitian yang dikaji dari pembelajaran membaca bahasa Inggris di Program Magister FITK UIN Syarif Hidayatullah Jakarta dapat disimpulkan bahwa pembelajaran bahasa Inggris di Program Magister FITK UIN Syarif Hidayatullah Jakarta berlangsung dengan baik. Pembelajaran ini dapat meningkatkan kemampuan membaca akademik yaitu memahami teks bahasa Inggris di lingkungan akademik. Kemampuan membaca tersebut diperoleh dari penggunaan teks yang bervariasi, menggunakan prosedur pramembaca, waktu membaca, dan pascamembaca yang dapat memfasilitasi mahasiswa menggunakan pendekatan membaca interaktif.

Saran peneliti berdasarkan temuan penelitian maka diberikan beberapa saran. Dosen bahasa Inggris harus menjelaskan tujuan pembelajaran membaca bahasa Inggris kepada mahasiswa serta manfaat dan bagaimana mencapainya. Dosen juga perlu menginformasikan atau menyiapkan bukubuku bahasa Inggris yang sesuai dengan kepentingan mahasiswa. Buku yang perlu dibaca mahasiswa sebaiknya disajikan di kelas terlebih dahulu, misalnya dengan memberikan satu judul dari setiap buku untuk dibaca dalam kelas yang berfungsi sebagai contoh sekaligus sebagai daya tarik agar mahasiswa memiliki minat untuk membaca judul-judul lainnya di luar kelas.

Kunci keberhasilan pembelajaran membaca adalah mahasiswa harus banyak membaca, dengan demikian, dosen seharusnya dapat meyakinkan mahasiswa perlunya banyak membaca. Untuk kepentingan ini maka dosen seharusnya memberikan tugas-tugas tambahan membaca di luar kelas dengan pengontrolan yang baik. Dosen bahasa Inggris harus dapat memberikan kemudahan kepada mahasiswa untuk dapat memperoleh bahan-bahan bacaan yang sesuai dan tepat. Mahasiswa harus menyadari bahwa keberhasilan dalam belajar bukan hanya menjadi tanggung jawab dosen tetapi sebagian besar ditentukan oleh mahasiswa itu sendiri.

\section{DAFTAR PUSTAKA}

Beer, T. (2007). Schema- Theoretic Models of Reading: Humanizing The Machine, Reading Research Quantely 22(3), 36-37

Bolinger, D. (2002). Aspect of Language. Englewood Cliffs: Prentice Hall.

Coady, J. \& Barkman, B. (2009). Reading in a Second Languages. Rowlet: Newsbury House

De Lopez, C. C.; Marcie, G \&Ariazza-Coyle, M. E. (2007) A Taxonomy: Evaluating: Reading Comprehension in EFL. Forum 35(2), 30-35. 
Harris, L. T. \& Hodges, R. E. (2000), A Dictionary of Reading. New York: New York Publisher.

Kaplan, R. B \& Shaw, P. A. (2003). Exploring Academic Discourse : A Textbook for Advanced Level ESL Reading and Writing Students. Massachuset: Newbury House.

Kendall, J., Mason, J. \& Hunter, W. (2000). Which Comprehension? Artifacts in The Measurement of Reading Comprehension. Journal of Education Research (73), 233-236

Langer, J. (2002). Facilitating Text Processing: The Elaboration of Prior Knowledge. Dalam J. Langer \& M. Smith - Burke (Eds), Reader Meets Author / Bridging The Gap : A Psycholinguistic and Sociolinguitic Perspective (pp. 30-45) New Work, DE : International Reading Association.

Mackey, F. W. (2006) Language Teaching Analyisis. London: Longmans, Green \& Co.

Mason, J. M. \& Kathryn A. H. (2006). Reading Instruction for Today. Illinois: Scott, Foresman and Co.

Miller, G. (2000). Psycholinguistics and Reading Process to Practice. Wintroph Publishers.

Murdick, R.G. \& Ross, J.E (2001). Information System in Modern Management. New Jersey: Prentice Hall, Inc.

Nuttal, C. (2007). Teaching Reading Skill in a Foreign Language. London: Heineman Educational Books.

Rossi, L. D., \& Gasser, M. (2003). Academic English. Englewood Cliffs, New Jersey: Prentice Hall, Inc.

Rubin, J. \& Thomson, I. (2005a). How to Be a More Succesful Language Learner. Boaton: Heinle and Heinle Publishers. (2005b). What the good language learner can teach us. TESOL Quarterly 9(1), 41-51.

Spradley, J. P. (1980). Participant Observation. California: Wadsworth.

Smith, F. (2000). Reading. Cambridge: Cambridge University Press,

Straiger, C R. (2003). The Teching of Reading. Paris: Unesco/Ginn,

Stren, H. (2008). What can we learn from the good language learner? The Canadian Modern Language Review 31(4), 304-318.

Widdowson. H.G, (2003) Teaching Language as Comunication. Paris: Unesco / Ginn 